This item was submitted to Loughborough's Research Repository by the author.

Items in Figshare are protected by copyright, with all rights reserved, unless otherwise indicated.

\title{
A Quality-by-Design approach to risk reduction and optimization for human embryonic stem cell cryopreservation processes
}

PLEASE CITE THE PUBLISHED VERSION

http://dx.doi.org/10.1089/ten.tec.2013.0595

\section{PUBLISHER}

(C) Mary Ann Liebert

\section{VERSION}

AM (Accepted Manuscript)

\section{PUBLISHER STATEMENT}

This work is made available according to the conditions of the Creative Commons Attribution-NonCommercialNoDerivatives 4.0 International (CC BY-NC-ND 4.0) licence. Full details of this licence are available at: https://creativecommons.org/licenses/by-nc-nd/4.0/

\section{LICENCE}

CC BY-NC-ND 4.0

\section{REPOSITORY RECORD}

Mitchell, Peter D., Elizabeth Ratcliffe, Paul C. Hourd, David J. Williams, and Robert James Thomas. 2017. "A Quality-by-design Approach to Risk Reduction and Optimization for Human Embryonic Stem Cell Cryopreservation Processes". figshare. https://hdl.handle.net/2134/26152. 
LOUGHBOROUGH UNIVERSITY

\title{
A Quality by Design approach to risk reduction \&
}

\section{optimisation for hESC cryopreservation processes}

\author{
Peter D. Mitchell $\stackrel{a}{,}$ Elizabeth Ratcliffe $\stackrel{a}{a}$, Paul Hourd $\stackrel{a}{\underline{a}}$, Julie Kerby ${ }^{b}$, David J. Williams $\stackrel{a}{a}$, Robert \\ J. Thomas $\underline{a}^{\star}$
}

aHealthcare Engineering Research Group, Centre for Biological Engineering, Wolfson School of Mechanical and Manufacturing Engineering, Loughborough University, Loughborough, Leicestershire, LE11 3TU, United Kingdom.

${ }^{b}$ Pfizer Neusentis, Granta Park Research Centre, Cambridge, CB21 6GS, United Kingdom.

P.D.Mitchell, PhD: P.D.Mitchell@lboro.ac.uk, Tel no. +441509564889

E.Ratcliffe, PhD: E.Ratcliffe@lboro.ac.uk, Tel no. +441509564889

P.Hourd, PhD: P.Hourd@lboro.ac.uk, Tel no. +441509564889

J.Kerby, PhD: Julie.Kerby@pfizer.com.Tel no. +441304643485

D.J.Williams, REng BSc PhD DEng CEng FIMechE FIEE FIMMM MInstD: D.J.Williams2@lboro.ac.uk, Tel no. +441509227668

*Corresponding author: R. J. Thomas, PhD; Healthcare Engineering Research Group, Centre for Biological Engineering, Wolfson School of Mechanical and Manufacturing Engineering, Loughborough University, Loughborough, LE11 3TU, United Kingdom. Telephone: +44-1509-227601, Fax: +441509-564894, E-mail address:R.J.Thomas@lboro.ac.uk 


\section{Introduction}

The Regenerative Medicine ( $\mathrm{RM})$ industry requires the ability to manufacture high quality cell-based therapies at an economically acceptable cost and clinically acceptable quality if it is to achieve mass market application and impact many degenerative and currently incurable diseases (1). Human embryonic stem cells (hESCs) are of significant importance as a potentially renewable source of cells for RM applications due to their ability to self-renew indefinitely and retain the potential to differentiate into every cell type $(2,3)$. However, robust and scalable manufacturing processes that meet the cost/quality objectives to enable efficient production and clinical uptake have been elusive.

Complex processes require a systematic approach to develop understanding of key controls that reduce the risk of process failure. Quality by Design $(Q b D)$ is the current paradigm for pharmaceutical product and bioprocess design (4-6), incorporating tools to address these issues, including risk assessment, process mapping, and factorial Design of Experiments (DoE; 4,5). Risk assessment ensures capital is allocated efficiently to high risk areas. Process mapping ensures a consensual understanding of process issues and variables. DoE enables efficient understanding of key variables identifed in process mapping. Such tools are central to product development and manufacturing systems for delivering consistent quality $(9,10)$.

Applying QbD approaches to cell therapy products has additional challenges compared to conventional pharmaceuticals. $\mathrm{QbD}$ relies on an understanding of critical quality attributes (CQAs) that determine the products performance. A scientific understanding of process and other operational risks that may detrimentally affect these attributes can then be developed. However, cell therapy products do not currently have complete measureable CQA profiles that guarantee function through mechanistically understood relationships. Further, processes typically involve numerous biological input materials that are equally poorly defined and have limited in-process monitoring and control of key variables (1). Resultant statistically 
uncontrolled or high intrinsic variation processes are very challenging to characterise at a level expected for manufacturing and have led to production processes with poor control and significant endpoint quality testing and wastage. This results in high risk product manufacture from a regulatory and economic perspective, a situation exacerbated by the restricted ability to purify the end product $(11,12)$ which increases the criticality of the entire bioprocess to the integrity of the end-product relative to molecular therapies (13).

Our process risk assessments, both with industrial partners and in-house processes, have repeatedly highlighted product cryopreservation as a highly variable and high risk process step for hESC bioprocesses. It is well documented that cryopreservation and resuscitation of hESCs is complex and ill-defined leading to recovery rates as low as $5 \%$ and undesirable cell differentiation (14). We therefore selected it as the unit operation focus to explore the potential for a $\mathrm{QbD}$ driven approach for process improvement.

There are two primary techniques used for cryopreservation of hESCs; slow freezing (15-17) and vitrification (18-20). Although vitrification can result in high viability and improved resuscitation survival compared to most slow freezing protocols $(18,21)$, the technique is significantly limited for cGMP (current Good Manufacturing Practise) of RM cellular therapies. The limitations pertain to achievable scale and process complexity, and potential regulatory concerns regarding the use of very high concentrations of cryoprotective agents (CPAs), $\mathrm{LN}_{2}$ contact, and potential for contamination and cross-contamination (18). Slow freezing processes confer advantages for cGMP in terms of increased achievable scale (large numbers of cells or colonies per cryovial), process simplification, lower CPA concentrations, alternatives to direct $\mathrm{LN}_{2}$ contact, and more appropriate storage systems for mitigation of contamination and cross-contamination risks (21). Slow freezing is currently widely employed in the cell therapy industry and was therefore selected as the focus for this study where we have applied robust process design and QbD principles to define a low-risk, high 
quality process for the unit operation of hESC colony culture cryopreservation and resuscitation.

\section{Materials and Methods}

A set of in-house SOPs and process maps of the culture, cryopreservation and resuscitation sub-steps were used to reduce experimental noise. These maps showed high level points of control (e.g. timed sub-steps, temperatures), points of measurement, and the measurement systems used.

\section{1. hESC culture and maintenance}

The hESC line, H9 (WiCell Research Institute, p25) was cultured on growth factor reduced hESC-qualified Matrigel ${ }^{\mathrm{TM}}$ (BD Biosciences) in mTeSR1 medium (StemCell Technologies). Working cell banks (p36) for these studies were cryopreserved in this format in mFreSR medium (StemCell Technologies), using a Nalgene Mr Frosty (Thermo Scientific) held at $80^{\circ} \mathrm{C}$ for $18 \mathrm{~h}$ before being transferred to $\mathrm{LN}_{2}$ vapour phase storage. Experimental cultures (p37-42) were maintained in 6-well plates at $37^{\circ} \mathrm{C}, 5 \% \mathrm{CO}_{2}$ in a humidified atmosphere with medium change every $24 \mathrm{~h}$. Intact colony dissociation for passage was performed with Dispase (StemCell Technologies, $1 \mathrm{mg} / \mathrm{ml}$ ). Cultures were morphologically assessed for $\sim 70 \%$ confluence and $<20 \%$ differentiation at passage (approx. $4-5$ days between each passage) with manual removal of excessive differentiation. Temperature control was monitored throughout the study using MSR®145 dataloggers (MSR Electronics GmbH, Henggart, Switzerland). Assessment of cell pluripotency was performed using the Guava EasyCyte 8HT Flow Cytometer (Millipore) and the following conjugated antibodies and appropriate isotype controls, used according to manufacturer's instructions: NanogAlexafluor 488 (AF488), Oct4a-AF488, SOX2-AF488 (BD Biosciences). 


\subsection{Cryopreservation protocol}

Detached colonies were transferred to a $50 \mathrm{ml}$ tube and centrifuged at $300 \mathrm{~g}$ for $5 \mathrm{~min}$. The supernatant was gently aspirated and mFreSR was slowly added to the cell pellet $(1 \mathrm{ml} /$ dissociated well) and mixed gently. The cell solution was aliquoted into Nunc cryovials at $1 \mathrm{ml} / \mathrm{vial}$ using a $5 \mathrm{ml}$ stripette. Cryovials were cooled to $-80^{\circ} \mathrm{C}$ at experimental freeze rates using an Asymptote EF600 controlled rate freezer (Cell Cryogenics Ltd., Cambridge, UK) or Nalgene Mr Frosty and held at $-80^{\circ} \mathrm{C}$ for $12 \mathrm{~h}$; cells were then transferred to $\mathrm{LN}_{2}$ vapour phase storage.

\subsection{Resuscitation protocol}

mTeSR1 was pre-warmed to $37^{\circ} \mathrm{C}$, and matrigel-coated 24 -well plates were warmed to room temperature. Cryovials were thawed at experimental temperatures and times in a waterbath. $1 \mathrm{ml}$ mTeSR1 was added slowly to each cryovial and gently mixed. The cell suspension was transferred to a $15 \mathrm{ml}$ tube (separate tube per cryovial) and an additional $4 \mathrm{ml} \mathrm{mTeSR} 1$ gently added. Colonies were pelleted by centrifugation ( $300 \mathrm{~g}$ for $5 \mathrm{~min}$ ) and gently resuspended in $2 \mathrm{ml}$ mTeSR1. Using a $5 \mathrm{ml}$ stripette, the $2 \mathrm{ml}$ cell suspension was used to seed wells in triplicate at $0.5 \mathrm{ml} /$ well. Cells were incubated at $37^{\circ} \mathrm{C}, 5 \% \mathrm{CO}_{2}$ for $1 \mathrm{~h}$ and then removed for analysis of adherence and viability.

\subsection{Cell adherence and viability assay}

Culture supernatant was transferred to individual eppendorf tubes. Wells were gently washed with $0.5 \mathrm{ml}$ DMEM/F12 (Life Technologies) and added to the supernatant samples. To dissociate colonies into a single cell suspension, $0.5 \mathrm{ml}$ Accutase (StemCell Technologies) was added per well and the cells incubated at $37^{\circ} \mathrm{C}$ for $15 \mathrm{~min}$. Dissociated samples were transferred to separate eppendorfs, the wells washed with $0.5 \mathrm{ml}$ DMEM/F12 and the wash solution added to the dissociated samples. The supernatant and dissociated samples were centrifuged at $300 \mathrm{~g}$ for $5 \mathrm{~min}$, resuspended in $700 \mu \mathrm{l} 0.01 \mu \mathrm{M}$ calcein AM live cell stain (Life Technologies) and incubated at $37^{\circ} \mathrm{C}$ for $7 \mathrm{~min}$. Samples were then plated into a 96 -well 
round bottomed plate at $200 \mu \mathrm{l} /$ well (each sample in triplicate) and analysed for Calcein AM expression using a Guava EasyCyte 8HT Flow Cytometer. Adherence was calculated by dividing the number of cells in the dissociated sample by the total number of cells in both the supernatant and dissociated samples. Viability was measured by calculating the percentage of cells expressing over a set level of fluorescence (Figure 1). Controls included non-frozen cells and unstained cells.

\subsection{Experimental designs}

A systematic approach was used to evaluate the effect of various formulation and process variables on the health of cells during the cryopreservation and resuscitation sub-processes. Experimental factors for investigation were selected from risk assessments and review of process maps. The adherence based viability assay described above was used as an experimental response. All experimental designs were created and analysed using Design Expert 8.0.7.1 (Stat-Ease Inc. MN, USA). ANOVA was applied to establish a prediction model for each response. A two replicate, two level, central composite design $\left(2^{4}\right)$ was employed to investigate the cryopreservation sub-processes. Experimental parameter levels were set around normal process levels within limits of practicality (i.e. avoiding excessive confluence or cryopreservation time $(\geq 3 \mathrm{~h})$. Centre points for each variable were included to make the design more robust and enhance the predictive power of the model. Experiments were randomised as far as possible within operational constraints. A 2-level, fractional factorial design with 8 centre points was used to investigate the resuscitation sub-process. Input culture quality was varied using data from the cryopreservation sub-process experiment to select a sub-optimal and optimal set of freeze conditions. The selected models were evaluated according to a range of adequacy tests. Data was transformed if required prior to modelling and insignificant terms were removed using backwards selection. Diagnostics data was used to determine best fit for model selection. 


\section{Results}

The objective of this work was to develop a systematic approach, in line with QbD concepts, to increase quality and recovery of cryopreserved hESC colonies and to reduce process risk. A screening exercise identified a suitable assay for detecting damage to cells postresuscitation with the speed, throughput and sensitivity to enable a DoE approach. A process map identified key variables for a series of designed experiments to identify critical determinants of hESC quality during the cryopreservation and resuscitation process.

\subsection{Establishing a Cell Assay for Recovery from Cryopreservation}

Application of multi-factorial experiments for efficient and robust process design depends upon high-throughput, rapid, and accurate post-resuscitation measurement to predict longterm recovery (a key CQA). Using two different cryopreservation protocols (controlled rate freeze at $1^{\circ} \mathrm{C} / \mathrm{min}$ and $2^{\circ} \mathrm{C} / \mathrm{min}$ ), we analysed multiple cell attributes up to $96 \mathrm{~h}$ postresuscitation for their ability to predict recovery. These attributes included adherence, cell esterase activity (Calcein AM), apoptosis (Caspase 3, 8 \& 9), membrane integrity (CellROX), pluripotency (Nanog, Oct4, Tra-1-60, Tra-1-81, SSEA1 and SSEA4) and proliferation (Ki67). Early measurement of cellular adherence and viability of adhered cells (by cell esterase activity; Calcein AM, $1 \mathrm{~h}$ post seeding) correlated with 4 day proliferation data and allowed early discrimination between cell recovery from different freeze conditions (Figure 2A, B). Cells would continue to adhere and recover esterase activity beyond the first hour, but the extent of recovery after one hour was good enough to predict long term recovery. However, due to measurement as early as $1 \mathrm{~h}$ post seeding, values for adherence and viability appeared relatively low. Adherence was selected as a primary quality output due to highest sensitivity to long-term recovery in response to process variation; cell esterase activity was used as a secondary quality output as it provided a further layer of information on the health of the adhered cells. Instability in the Calcein AM viability assay was observed over time (Figure $2 \mathrm{C}$ ); removal of a wash step after staining resulted in prolonged signal stability as cells were able to continue cleaving Calcein AM, thus maintaining viable cell fluorescence 
(Figure 2D). This modified method had the throughput and stability required to assess hES recovery from cryopreservation experiments and develop models of the cryopreservation process.

\subsection{Establishing cryopreservation experimental parameters and analysis}

A risk assessment of hESC cryopreservation and resuscitation was produced following a systematic review of existing protocols and literature. This enabled identification of process parameters amenable to experimental optimisation and control (Table 1). Parameter levels for each prioritised factor listed in Table 1 were set at low, medium (where possible), or high for the experimental designs and models (see Table 2). This identified the necessity to split experimental planning into two sub-units (cryopreservation and resuscitation) to pragmatically restrict experiment size. Experimental designs were conducted in triplicate and the cell recovery measured with the method established in 3.1. This data was used to generate statistical models of the effect of the experimental parameters on the cell recovery in terms of both cell adherence and viability of adhered cells. All models passed standard regression diagnostics and lack of fit tests, and correlation plots of predicted vs. experimental values (as well as $\mathrm{R}^{2}$ values) indicated models should be predictive. The signal-to-noise ratio of the data was adequate ( $>4)$, and analysis via ANOVA found the experimental models to be significant $(p<0.001)$. See supplemental 1 for a summary of the DoE model analysis for the cryopreservation and resuscitation sub-processes.

\subsection{Effect of cryopreservation parameters on cell quality and definition of the optimal process operating space}

Cell recovery positively correlated with longer pre-culture duration and slower freeze rates (Figure 3A), but was insensitive to cryoprotectant volume and temperature (within the experimental range). The model of adherence predicted that optimisation of significant factors could improve adherence from $27.0 \%$ to $62.2 \%$. Minor model curvature was observed within both pre-culture duration and freeze rate, indicating that the factor ranges 
used may be near optimal for adherence. The model describing the viability of adhered cells was reassuringly similar to that of total cell adherence i.e. increasing with longer pre-culture duration. However, when using this quality measure, freeze rate only had a minor impact and was not independent of pre-culture duration; a peak in viability (55-58\%) was observed across all freeze rates at 5.8-6.8 days in pre-culture (Figure 3B).

Process design space optimisation was performed using minimum desired values of $60 \%$ adherence and $50 \%$ viability of adhered cells at $1 \mathrm{hr}$ post seed. This is a software function that uses the process models to calculate a parameter operating tolerance in order to consistently deliver product within specification. Minimum desired values must be selected from within the experimental data range. Cryoprotectant volume and temperature were set at $0.5 \mathrm{ml}$ and $4^{\circ} \mathrm{C}$ respectively, as the models predicted no effect on cell quality and these settings improved economy and ease of control. The optimal experimental design space (see Figure 3C), confirmed that longer pre-culture times coupled with lower freeze rates are optimal for cell recovery.

\subsection{Establishing resuscitation experimental parameters and analysis}

To determine the relationship between the cryopreservation sub-process described above (3.3) and the linked resuscitation sub-process, we created two cryopreserved cell populations using an optimal and significantly sub-optimal freeze process (based on the output of the above cryopreservation models). These populations were used as alternative ('good' and 'bad') inputs to screen the resuscitation process parameters identified in Table 2. Importantly, this highlighted how the ability of resuscitation parameters to affect the cell recovery, either positively or negatively, is dependent on the cryopreservation of the resuscitated sample. 


\subsubsection{Effect of parameters on cell adherence}

Thaw bath temperature, exposure time of cryovial in thaw bath, and temperature of the dilution media added to the thawed cells all had significant effects on cell adherence, with the latter two factors being non-independent. Seeding density did not have a significant effect. Cryopreserved input cell quality (optimal vs. sub-optimal) was significant but nonindependent of all other factors. Thaw bath temperature was only significant for the suboptimally cryopreserved input cells, where a higher temperature increased cell adherence by up to $11 \%$. Also, longer exposure in the thaw bath and a higher dilution media temperature both significantly improved recovery of sub-optimally cryopreserved cells (up to $9 \%$ increase in adherence) regardless of other factors. Optimally cryopreserved cells were less sensitive to the resuscitation process: thaw bath exposure time and dilution media temperature interacted such that they only affected cell adherence when the other factor was set at a low level; if exposure time of cells was low, adherence increased up to $20 \%$ at higher dilution media temperatures. Optimisation of exposure time or dilution media temperature increased robustness of the process to variation in the other factor, thus longer exposure times resulted in improved adherence and increased robustness to variations in dilution media temperature. The adherence model indicates that high levels of each significant factor would produce the most robust, optimal resuscitation process for both optimal and sub-optimal cryopreserved cells.

\subsubsection{Effect of parameters on adhered cell viability (Calcein AM)}

The Calcein AM viability assay provided limited additional information on the effect of resuscitation parameters beyond the adherence assay. It confirmed that a longer exposure time in the thaw bath improved the cell recovery (by up to $10.3 \%$ ) and that parameters affected the sub-optimally cryopreserved cells more than the optimally cryopreserved. In addition to the adherence data, a higher seeding density had a minor beneficial effect to cell viability in both inputs. The viability model indicated that high levels for all significant factors improved the resuscitation process for both optimal and sub-optimal cryopreserved cells. 


\subsection{Design spaces}

The details of the models described in 3.4.1 and 3.4.2 can be combined to generate process design (Figure 4A, B) and desirability (Figure 4C, D) charts using both cell adherence and cell viability responses to predict parameter levels that will deliver cells above minimum selected specification. Optimal regions for both cell quality inputs were found at high levels of thaw temperature, exposure time and dilution media temperature. Optimisation of both the cryopreservation and resuscitation sub-processes predicted significant improved adherence and recovery of cryopreserved cells (Table 3 ).

\subsection{Model validation}

Due to the inherent interaction of the cryopreservation and resuscitation sub-processes, model validation was performed simultaneously as a single complete process to allow measurement of cell quality post cryopreservation. All values observed in the validation runs were within an acceptable range of the predicted values, thus validating the models (Figure 5A). Analysis of typical pluripotency markers Nanog, Oct4a, and Sox2, showed no detectable differences pre and post-cryopreservation (Figure 5B). Extended culture (96h post seeding) of optimally cryopreserved inputs demonstrated a rapid recovery of proliferation after a lag phase of $24 \mathrm{~h}$ (Figure $5 \mathrm{C}$ ); suboptimal inputs demonstrated a lag phase of up to $48 \mathrm{~h}$ (Figure $5 \mathrm{C}$ inset).

\section{Discussion}

This study demonstrates the application of a $\mathrm{QbD}$ approach to gain further understanding of the processes involved in cryopreservation and resuscitation of therapeutic cells. Tools used include risk assessment, CQA selection and multi-factorial statistically designed experiments and models. These methods would be utilised by a manufacturer to develop models and validate the operating conditions for their specific cell bank. This $\mathrm{QbD}$ type approach offers an improvement over less systematic and one factor experimental methods. It increases experimental efficiency, enables detection of interactions between processing 
variables, and allows a risk-driven quantitation of process sensitivities, therefore enabling development of scientifically informed process control strategies. It is also a model for development of cell manufacturing processes through division into manageable subprocesses which facilitates sytematic characterisation and engineering control. hESC colony culture cryopreservation is explored as an exemplar due to its complexity, common poor cell recovery, and associated process risk (14).

There are mutiple steps required to design the cryopreservation and resuscitation operating spaces to reduce process risk. These include identifying sub-process outputs that are directly predictive of the subsequent process (and ultimately product) performance (a critical process or quality attribute). Correct identification ensures that successfully controlling output from one sub-process will determine the performance of the next. Some of these outputs, such as cell viability, are intuitive; a wide distribution of viability will clearly impact cell quality further down the process (2). It is therefore a good initial target relative to pluripotency factors or surface marker measurements where a quantitative and timely link to cell quality is poorly defined (32). Further, detecting physical damage from cryopreservation is unlikely to immediately manifest in pluripotency markers. This does not mean these attributes are not important; they just may not be relevant for rapid detection of a changed output from this specific sub-process. For this same reason, the common method of testing cells for karyotypic change after cryopreservation was not performed because the nature of karyotypic change suggests that a prolonged growth period would be required to detect the emergence of a karyotypically abnormal population. Furthermore, the stochastic nature of karyotypic change would require a very large number of experimental runs to statistically determine the relationship between cryopreservation conditions and karyotypic stability.

Many current assays are based on cell viability, however, these are often invasive and open to interpretation. For example membrane integrity methods are not sensitive to cells that succumb to delayed onset cell death and do not give information on proliferating cells (33), 
and measures of metabolic activity (34) that can fluctuate independent of viability. We investigated the performance of conventional viability tests both at product defrost and at other points in the manufacture process to determine those that are most predictive of longer term cell health; many were insensitive with regard to predicting cell recovery. The cell adherence system we report was a rapid, high-throughput and stable measurement of postcryopreservation cell recovery. We observed that measurement of adherence and viability of adhered cells at 1 hour post seeding was predictive of cell proliferative ability after 96 hours in this system.

In a limited number of experimental conditions the cell adherence and cell viability by esterase activity were contradictory; this resulted in a dilemma whereby adherence was optimal at certain factor levels, but viability was optimal at others. In this study our design spaces selected for the weighting of adherence and viability that resulted in the greatest numbers of viable recovered cells for manufacturing. This is an example of the care required in meaningfully interpreting CQAs and model outputs. The complexity of therapeutic cell responses suggest that using multiple modelled outputs to generate agreement in the effect of processing parameters will be important to reduce risk of misinterpreting findings.

The factors selected in the models for cryopreservation and resuscitation were chosen based on both their prominence in literature and our previous studies suggesting influence on cryopreserved cell quality. Although the models allow substantial process improvement, the noise in the data indicates that there are one or more factors that introduce variation that are not fully controlled. This variation may come from the existing variation in the cell lines used, operator variation, or from environmental effects such as variation in room temperature. QbD methodology, as a risk driven process, should continue to target variables until adequate control and process knowledge can be demonstrated commensurate with process risk. Response surface models can be used to provide higher resolution models of relationships if required to predict process performance. However, selection of both further 
variables and more intensive experimental designs require significant resource and require risk based justification to allocate capital.

The models used for cryopreservation and resuscitation steps indicate that both subprocesses are critical to cell recovery. Pre-culture duration and freeze rate were identified as critical parameters affecting the cryopreservation sub-process. This data agrees with the current trends observed in literature, stating that hESCs require sufficient time post-passage to recover E-cadherin, essential for their survival (22). It is clear that cell state as a function of culture time is a critical indicator of cell robustness to cryopreservation. However it is currently unclear how this could be accurately measured (we noted a decrease in EdU incorporation with longer culture which may be a candidate predictive assay). Evidence suggests a faster freeze rate is beneficial with DMSO based cryoprotectants as it protects cells from toxicity. However, we found that a slower freeze rate was optimal, potentially due to increased time for equilibration of DMSO throughout colonies, reducing intracellular ice formation.

All factors tested in the resuscitation model had an effect, either individually or in interaction with one another. The effect of seeding density on cell recovery showed substantial noise, most likely due to the challenges of controlling colony seeding density based on the dilution factor of a vial rather than specific cell counts. Cells treated with a short exposure time had increased adherence when resuspended in warmer media. Use of warm resuspension media increased robustness of cell viability to variations in thaw temperature, this is likely due to it aiding rapid defrost of still-frozen cell solutions (29). In samples with longer exposure times, cell solutions were already defrosted and therefore are less affected by lower dilution media temperatures. This data suggests that a rapid solid-to-liquid transition is the most critical part of the resuscitation process to maintain cell health. 
The interdependence of cryopreservation and resuscitation indicate that although poorly frozen cells will not recover to levels observed with optimal freezing protocols, it is possible to significantly improve adherence and viability of the cells through controlled defrost, thus increasing the total yield available for manufacture. The ability to improve the robustness of the defrost process to variations in cryopreservation or vice versa potentially reduces one of the sub-processes that needs stringent control during manufacturing and improves logistical flexibility. This is exemplified in the resuscitation model where many parameters had a greater effect on poorly cryopreserved input samples relative to optimally cryopreserved samples. The process confidence delivered by such systematic modelling methods has the potential to greatly facilitate regulatory acceptance of new cell products, define operational boundaries (and therefore logistics and costs) and reduce risk for product developers.

\section{Acknowledgements}

The authors gratefully acknowledge the financial support from Pfizer Neusentis and the EPSRC centre for regenerative medicine. The authors acknowledge Miss Kirsty-Louise Marrow for her laboratory support and technical input. The authors also acknowledge Dr Andrew Picken and Dr Katie Glen at the Centre for Biological Engineering, Loughborough University for their constructive discussions and useful input.

\section{Author disclosure statement}

No competing financial interests exist 


\section{References}

1. Ratcliffe E, Thomas RJ, Williams DJ. Current understanding and challenges in bioprocessing of stem cell-based therapies for regenerative medicine. Br Med Bull. 100(1), 137, 2011.

2. Thomson H. Bioprocessing of embryonic stem cells for drug discovery. Trends Biotechnol. 25(5), 224, 2007.

3. Horton RE, Millman JR, Colton CK, Auguste DT. Engineering microenvironments for embryonic stem cell differentiation to cardiomyocytes. Regen Med. 4(5), 721, 2009.

4. Juran JM. Juran on Quality by Design: The New Steps for Planning Quality Into Goods and Services. Free Press; p. 538, 1992.

5. Defeo J, Juran JM. Juran's Quality Handbook: The Complete Guide to Performance Excellence 6/e. McGraw Hill Professional; p. 1136, 2010.

6. Rathore AS, Winkle H. Quality by design for biopharmaceuticals. Nat Biotechnol. 27(1), 26, 2009.

7. Fisher RA. The Design of Experiments. Macmillan Pub Co; p. 250, 1971.

8. Stamatis DH. Six Sigma Fundamentals: A Complete Introduction to the System, Methods, and Tools: A Complete Guide to the System, Methods, and Tools . Productivity Press; p. 368, 2003.

9. Poon GKK, Chan JSF, Williams DJ. Experimental study of workpiece-level variability in blind-via electroplating. Proc Inst Mech Eng, B J Eng Manuf. 215(4), 521, 2001. 
10. Abu-Absi SF, Yang L, Thompson P, Jiang C, Kandula S, Schilling B, et al. Defining process design space for monoclonal antibody cell culture. Biotechnol Bioeng. 106(6), 894, 2010.

11. Schriebl K, Lim S, Choo A, Tscheliessnig A, Jungbauer A. Stem cell separation: a bottleneck in stem cell therapy. Biotechnol J. 5(1), 50, 2010.

12. Rayment EA, Williams DJ. Concise review: mind the gap: challenges in characterizing and quantifying cell- and tissue-based therapies for clinical translation. Stem cells. 28(5), 996, 2010.

13. Mason C, Hoare M. Regenerative medicine bioprocessing: building a conceptual framework based on early studies. Tissue Eng. 13(2), 301, 2007.

14. Wagh V, Meganathan K, Jagtap S, Gaspar JA, Winkler J, Spitkovsky D, et al. Effects of cryopreservation on the transcriptome of human embryonic stem cells after thawing and culturing. Stem Cell Rev. 7(3), 506, 2011.

15. Whittingham DG, Leibo SP, Mazur P. Survival of mouse embryos frozen to -196 degrees and -269 degrees C. $\underline{\text { Science. }}$ 178(4059), 411, 1972.

16. Katkov II, Kim MS, Bajpai R, Altman YS, Mercola M, Loring JF, et al. Cryopreservation by slow cooling with DMSO diminished production of Oct-4 pluripotency marker in human embryonic stem cells. Cryobiology. 53(2), 194, 2006.

17. Deb K. A sweet potion to put embryonic stem cells to sleep. ScientificWorldJournal. 9, 236, 2009.

18. Reubinoff BE, Pera MF, Vajta G, Trounson a O. Effective cryopreservation of human embryonic stem cells by the open pulled straw vitrification method. Hum Reprod. 16(10), 2187, 2001. 
19. Karlsson JOM. Cryopreservation: freezing and vitrification. Science. 296(5568), 655, 2002.

20. L, I T, Zhou C, Liu C, Mai Q, Zhuang G. Bulk vitrification of human embryonic stem cells. Hum Reprod. 23(2), 358, 2008.

21. Amps KJ, Jones M, Baker D, Moore HD. In situ cryopreservation of human embryonic stem cells in gas-permeable membrane culture cassettes for high post-thaw yield and good manufacturing practice. Cryobiology. 60(3), 344, 2010.

22. Xu Y, Zhu X, Hahm HS, Wei W, Hao E, Hayek A, et al. Revealing a core signaling regulatory mechanism for pluripotent stem cell survival and self-renewal by small molecules. Proc. Natl. Acad. Sci. USA. 107(18), 8129, 2010.

23. Heng BC, Kuleshova LL, Bested SM, Liu H, Cao T. The cryopreservation of human embryonic stem cells. Biotechnol Appl Biochem. 41(Pt 2), 97, 2005.

24. Baust JM, Vogel MJ, Van Buskirk R, Baust JG. A molecular basis of cryopreservation failure and its modulation to improve cell survival. Cell Transplant. 10(7), 561, 2001.

25. Ji L, De Pablo JJ, Palecek SP. Cryopreservation of adherent human embryonic stem cells. Biotechnol Bioeng. 88(3), 299, 2004.

26. Lawson A, Mukherjee IN, Sambanis A. Mathematical modeling of cryoprotectant addition and removal for the cryopreservation of engineered or natural tissues. Cryobiology. 64(1), 1, 2012.

27. De Loecker W, Koptelov V a, Grischenko VI, De Loecker P. Effects of cell concentration on viability and metabolic activity during cryopreservation. Cryobiology. 37(2), 103, 1998. 
28. Yang P-F, Hua T-C, Tsung H-C, Cheng Q-K, Cao Y-L. Effective cryopreservation of human embryonic stem cells by programmed freezing. Conf Proc IEEE Eng Med Biol Soc. 1, 482, 2005.

29. Ware CB, Nelson AM, Blau CA. Controlled-rate freezing of human ES cells. BioTechniques. 38(6), 879, 2005.

30. Farrant J, Morris GJ. Thermal shock and dilution shock as the causes of freezing injury. Cryobiology. 10(2), 134, 1973.

31. Gao D, Critser JK. Mechanisms of cryoinjury in living cells. ILAR J. 41(4), 187, 2000.

32. Adewumi O, Aflatoonian B, Ahrlund-Richter L, Amit M, Andrews PW, Beighton G, et al. Characterization of human embryonic stem cell lines by the International Stem Cell Initiative. Nat Biotechnol. 25(7), 803, 2007.

33. Lim M, Ye H, Panoskaltsis N, Drakakis EM, Yue X, Cass AEG, et al. Intelligent bioprocessing for haemotopoietic cell cultures using monitoring and design of experiments. Biotechnol Adv. 25(4), 353, 2007.

34. Berridge M V, Tan AS. Characterization of the cellular reduction of 3-(4,5dimethylthiazol-2-yl)-2,5-diphenyltetrazolium bromide (MTT): subcellular localization, substrate dependence, and involvement of mitochondrial electron transport in MTT reduction. Arch Biochem Biophys. 303(2), 474, 1993. 
Figure 1. Histogram depicting the regions observed in populations of hESCs stained with Calcein AM. The viable region was utilised for determining the recovery of cells from cryopreservation. 


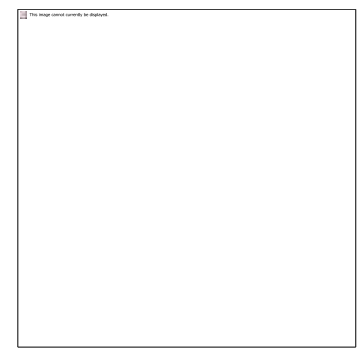

Figure 2. A difference in protocols that produced healthy (CRF1) or poor (CRF2) cell populations could be detected as early as $1 \mathrm{hr}$ post-resuscitation by analysing the adherence and viability of the adhered cells $(\mathrm{A})$ This was found to be predictive of rate of proliferation and recovery over 96 hours (B). Optimisation of the adherence based viability assay was required to prevent loss of fluorescent signal over time during analysis $(C)$. Signal longevity was proven for up to $2 \mathrm{hrs}$ following optimisation (D). Mean $\pm S D, n=3$ biological replicates (vials), 3 replicates per vial. Abbreviations: NFC - Non-frozen control; CPA - cryoprotectant agent exposed non-frozen control; CRF(n) - control rate freezer; $n$ - freeze rate (degrees per $\min )$. 


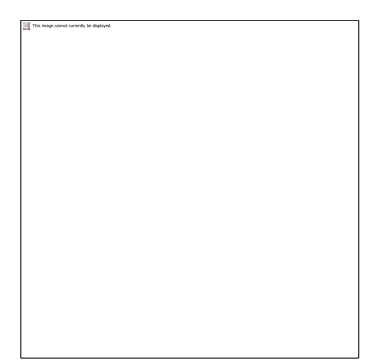

Figure 3. Contour heat plots demonstrating adherence and viability (combined together to provide a definition of cell health) within the cryopreservation DoE. High adherence/viability regions are red, low adherence/viability regions are blue. Adherence plots demonstrate that a longer pre-culture time (time since previous passage) and slower freeze rate promote best cell recovery $(A)$.The viability plot also demonstrates a peak of viability at later time points (B). Combination of both the adherence and viability data provides a design space for optimum cell health. Minimum desired values were set at $\geq 60 \%$ adherence and $\geq 50 \%$ viability. The \% adherence and \% viability lines demonstrate the parameter levels at which the average response will meet the minimum desired values. The yellow region depicts the region that parameters must be within to produce the minimum desired values for both adherence and viability. The \% viability PI (predictive interval) line takes into account statistical noise and shows the level where there is $95 \%$ confidence that the process will generate equal to or greater than $50 \%$ viability. It therefore defines a 'process operating window' with a known risk/safety margin. (C). 


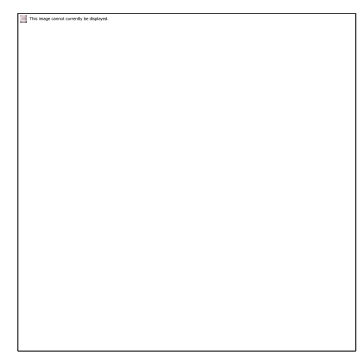

Figure 4. A combination of both the adherence and viability data was utilised to produce design spaces for optimum cell health and recovery from defrost for each cryopreserved input cell quality. The \% adherence and \% viability lines demonstrate the parameter levels at which the average response will meet the minimum desired values. The yellow regions depict the region that parameters must be within to produce the minimum desired values for both adherence and viability. $(A, B)$. (A) Optimal cryopreserved input with minimum desired values set at $\geq 70 \%$ adherence and $\geq 45 \%$ viability and (B) Suboptimal cryopreserved input with minimum desired values of $\geq 15 \%$ adhered and $\geq 25 \%$ viability. Figures $C$-D demonstrate the factor levels required to produce maximum adherence and viability (desirability). Values less than 1.0 occur when the optimal factor levels for adherence differ from the optimal factor levels for viability (or visa versa). In these situations a bias was given to the adherence data as factors demonstrated a greater affect on this response. Note: dilution media temperature and seeding density are set at high levels in all graphs. 


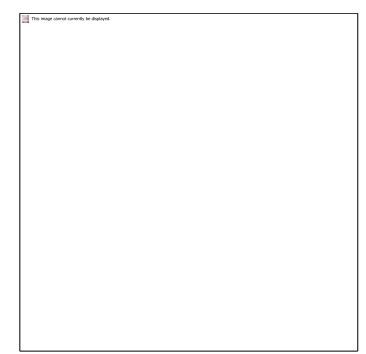

Figure 5. Validation plots proving the predictive ability of the models for both sub-processes are shown in $(A)$, while pluripotency markers for pre-cryopreservation and post-resuscitation are shown in (B). Recovery up to 96 -hours post seeding was analysed to confirm the quality of optimally resuscitated cells from optimal and sub-optimal cryopreservation samples (C, inset; expanded scale suboptimal recovery profile). Mean $\pm S D, n=3$ biological replicates (vials), 3 replicates per vial. 


\begin{tabular}{|c|c|}
\hline Factors & \begin{tabular}{|l|} 
Rationale \\
\end{tabular} \\
\hline $\begin{array}{l}\text { Time (days) since } \\
\text { previous passage (pre- } \\
\text { culture duration) }\end{array}$ & $\begin{array}{l}\text { Time in preculture effects colony proximity, confluence, and cell } \\
\text { media/paracrine microenvironment to partly determine cell phenotypic state } \\
\text { and therefore response to cryopreservation. This includes recovery of E- } \\
\text { cadherin and associated signalling (a cause of hESC death following } \\
\text { enzymatic dissociation }(22,23) \text {. }\end{array}$ \\
\hline $\begin{array}{l}\text { Cryopreservative } \\
\text { media temp }\left({ }^{\circ} \mathrm{C}\right)\end{array}$ & $\begin{array}{l}\text { DMSO-based cryoprotectants are known to be cytotoxic }(24,25) \text {. } \\
\text { Cytotoxicity and mass transfer are dependent on temperature, with a higher } \\
\text { temperature allowing more rapid mass transfer but also causing increased } \\
\text { cytotoxicity. Addition of cryoprotectants at a lower temperature is thought to } \\
\text { improve cell survival due to a lowered cellular metabolic activity. However, } \\
\text { the cold-shock and reduced mass transfer at low temperature is also } \\
\text { thought to have a negative effect on cell health }(26) \text {. }\end{array}$ \\
\hline $\begin{array}{l}\text { Cryopreservative } \\
\text { media volume }(\mathrm{ml})\end{array}$ & $\begin{array}{l}\text { Cell concentration during freezing has been shown to have an effect on cell } \\
\text { recovery through mechanical stress, increased intracellular ice formation, } \\
\text { and increased electrolyte concentration (27). } \\
\text { Cryoprotectant volume will affect the translation of controlled freeze rates to } \\
\text { the cells and also affect nucleation and ice formation during the cooling } \\
\text { process. }\end{array}$ \\
\hline te $\left({ }^{\circ} \mathrm{C} / \mathrm{min}\right)$ & $\begin{array}{l}\text { The cooling rate is one of the most recognised variables associated with } \\
\text { damage during cryopreservation. It affects multiple mediators of damage } \\
\text { such as nucleation, the rate of formation and the size of ice crystals, and } \\
\text { local solute concentrations. Different types of cells may require different } \\
\text { cooling rates }(28,29)\end{array}$ \\
\hline Thaw bath temp $\left({ }^{\circ} \mathrm{C}\right)$ & \multirow{2}{*}{$\begin{array}{l}\text { Thaw temperature and time of exposure to thaw temperature interact to } \\
\text { produce the thawing profile. Thaw profile is critical, with rapid thawing } \\
\text { previously shown to improve hESC recovery (29). It is essential to balance } \\
\text { a rapid thaw with maintaining cells at a viable temperature. }\end{array}$} \\
\hline $\begin{array}{l}\text { Exposure time to thaw } \\
\text { bath (min) }\end{array}$ & \\
\hline $\begin{array}{l}\text { Temp of dilution media } \\
\left({ }^{\circ} \mathrm{C}\right)\end{array}$ & $\begin{array}{l}\text { Contributes to the thawing profile. Temperature of the media upon addition } \\
\text { to defrosted cells may contribute to thermal shock (dilution shock) (30). }\end{array}$ \\
\hline
\end{tabular}




\begin{tabular}{|l|l|}
\hline Seeding density & $\begin{array}{l}\text { ESCs are dependent on cell-cell interactions for maintenance of viability } \\
\text { and pluripotency (23). High vs. Low colony seeding density will effect } \\
\text { proximity / paracrine signalling that may be key to cell resuscitation. }\end{array}$ \\
\hline $\begin{array}{l}\text { Quality of cells in } \\
\text { cryovial (i.e. degree of }\end{array}$ & $\begin{array}{l}\text { Quality of cryopreserved cells is a critical consideration to linking the } \\
\text { freezing and resuscitation processes. The effects of defrost on cell quality is } \\
\text { damage suffered }\end{array}$ \\
during & $\begin{array}{l}\text { dependent on the results of the freezing conditions, for example, whether } \\
\text { the rate of cooling has induced intracellular freezing or cell dehydration }\end{array}$ \\
\hline cryopreservation) & (31).
\end{tabular}

Table 1. List of prioritised factors for the designed experiments and a brief rationale for why they were chosen for the cryopreservation (white) and resuscitation (grey) sub-processes. 


\begin{tabular}{|c|c|c|c|}
\hline \multirow[t]{2}{*}{ Factors } & \multicolumn{3}{|l|}{ Levels } \\
\hline & Low & Medium & High \\
\hline Time (days) since previous passage & 3 & 5 & 7 \\
\hline Cryopreservative media temp $\left({ }^{\circ} \mathrm{C}\right)$ & 4 & 20.5 & 37 \\
\hline Cryopreservative media volume (ml) & 0.5 & 1.0 & 1.5 \\
\hline Freeze rate $\left({ }^{\circ} \mathrm{C} / \mathrm{min}\right)$ & 0.5 & 1.0 & 1.5 \\
\hline Thaw bath temp $\left({ }^{\circ} \mathrm{C}\right)$ & 27 & 37 & 47 \\
\hline Exposure time to thaw bath (min) & 1 & 2 & 3 \\
\hline Temp of dilution media $\left({ }^{\circ} \mathrm{C}\right)$ & 4 & 20.5 & 37.0 \\
\hline Seeding density & $1 / 2$ vial & - & Whole vial \\
\hline State of cells in cryovial & Suboptimal & - & Optimal \\
\hline
\end{tabular}

Table 2. Factors included in the designed experiments and the experimental levels of the variables (factors in white are from the cryopreservation DOE, factors in grey are from the resuscitation DOE) 


\begin{tabular}{|l|c|c|c|c|}
\hline & \multicolumn{2}{|c|}{ Suboptimal Resus. } & \multicolumn{2}{c|}{ Optimal Resus. } \\
\hline Input & Adhered (\%) & Viability (\%) & Adhered (\%) & Viability (\%) \\
\hline Optimal cryo. & 46.2 & 44.6 & 73.9 & 57.3 \\
\hline Suboptimal cryo. & 0.2 & 7.8 & 17.1 & 27.8 \\
\hline
\end{tabular}

Table 3. Increase in adherence of cells and viability of adhered cells by optimising the resuscitation process for either optimal or suboptimal cryopreserved input cells. Values were predicted using the DOE models based on raw data. 


\begin{tabular}{|l|l|}
\hline hESC & Human Embryonic Stem Cell \\
\hline CQA & Critical Quality Attribute \\
\hline QbD & Quality by Design \\
\hline DoE & Design of Experiments \\
\hline cGMP & Current Good Manufacturing Process \\
\hline CPA & Cryoprotectant \\
\hline LN & \\
\hline SOP & Liquid Nitrogen \\
\hline EdU & Standard Operating Procedure \\
\hline CRF & Control Rate Freezer \\
\hline NFC & Non-Frozen Control \\
\hline
\end{tabular}

List of abbreviations 
Supplemental 1: Summary of DOE analysis

\begin{tabular}{|c|c|c|c|c|c|}
\hline Source & $\begin{array}{l}\text { Sum of } \\
\text { Squares }\end{array}$ & df & $\begin{array}{l}\text { Mean } \\
\text { Square }\end{array}$ & F Value & $\begin{array}{l}\text { p-value } \\
\text { Prob }>F\end{array}$ \\
\hline Model & 37.90 & 4 & 9.47 & 40.84 & $<0.0001$ \\
\hline A-Time (Day) & 20.65 & 1 & 20.65 & 89.03 & $<0.0001$ \\
\hline D-Freeze Rate & 11.09 & 1 & 11.09 & 47.81 & $<0.0001$ \\
\hline$A^{\wedge} 2$ & 1.63 & 1 & 1.63 & 7.04 & 0.0104 \\
\hline$D^{\wedge} 2$ & 0.66 & 1 & 0.66 & 2.86 & 0.0966 \\
\hline Residual & 12.53 & 54 & 0.23 & & \\
\hline Lack of Fit & 5.27 & 20 & 0.26 & 1.23 & 0.2871 \\
\hline Pure Error & 7.26 & 34 & 0.21 & & \\
\hline Cor Total & 50.43 & 58 & & & \\
\hline
\end{tabular}

A reduced two-factor interaction model Summary of ANOVA analysis $\%$ adherence values in the cryopreservation model.

\begin{tabular}{|c|c|c|c|c|c|}
\hline Source & $\begin{array}{l}\text { Sum of } \\
\text { Squares }\end{array}$ & df & $\begin{array}{c}\text { Mean } \\
\text { Square }\end{array}$ & F Value & $\begin{array}{l}\text { p-value } \\
\text { Prob }>F\end{array}$ \\
\hline Model & 4887.94 & 14 & 349.14 & 70.69 & $<0.0001$ \\
\hline A-Time (Day) & 4120.00 & 1 & 4120.00 & 834.16 & $<0.0001$ \\
\hline B-Cryo Temp & 6.83 & 1 & 6.83 & 1.38 & 0.2459 \\
\hline C-Cryo Vol & 0.05 & 1 & 0.05 & 0.01 & 0.9230 \\
\hline D-Freeze Rate & 1.52 & 1 & 1.52 & 0.31 & 0.5814 \\
\hline$A B$ & 5.17 & 1 & 5.17 & 1.05 & 0.3116 \\
\hline$A C$ & 7.89 & 1 & 7.89 & 1.60 & 0.2130 \\
\hline $\mathrm{AD}$ & 143.23 & 1 & 143.23 & 29.00 & $<0.0001$ \\
\hline $\mathrm{BC}$ & 1.71 & 1 & 1.71 & 0.35 & 0.5596 \\
\hline $\mathrm{BD}$ & 4.89 & 1 & 4.89 & 0.99 & 0.3251 \\
\hline CD & 7.72 & 1 & 7.72 & 1.56 & 0.2177 \\
\hline$A^{2}$ & 407.10 & 1 & 407.10 & 82.42 & $<0.0001$ \\
\hline $\mathrm{B}^{2}$ & 0.45 & 1 & 0.45 & 0.09 & 0.7635 \\
\hline
\end{tabular}




\begin{tabular}{|l|c|c|c|c|c|}
\hline $\mathrm{C}^{2}$ & 5.39 & 1 & 5.39 & 1.09 & 0.3020 \\
\hline $\mathrm{D}^{2}$ & 26.91 & 1 & 26.91 & 5.45 & 0.0242 \\
\hline Residual & 217.32 & 44 & 4.94 & & \\
\hline Lack of Fit & 34.89 & 10 & 3.49 & 0.65 & 0.7606 \\
\hline Pure Error & 182.43 & 34 & 5.37 & & \\
\hline Cor Total & 5105.26 & 58 & & & \\
\hline
\end{tabular}

Summary of ANOVA analysis on \% viability of adhered in the cryopreservation model.

\begin{tabular}{|c|c|c|c|c|c|}
\hline Source & $\begin{array}{l}\text { Sum of } \\
\text { Squares }\end{array}$ & df & $\begin{array}{l}\text { Mean } \\
\text { Square }\end{array}$ & F Value & $\begin{array}{l}\text { p-value } \\
\text { Prob }>\text { F }\end{array}$ \\
\hline Model & 14.81 & 11 & 1.35 & 273.09 & $<0.0001$ \\
\hline A-Thaw Temp & 0.23 & 1 & 0.23 & 47.60 & $<0.0001$ \\
\hline B-Exposure Time & 0.27 & 1 & 0.27 & 55.46 & $<0.0001$ \\
\hline C-Dilution Media temp & 0.36 & 1 & 0.36 & 72.77 & $<0.0001$ \\
\hline D-Seeding Density & 0.02 & 1 & 0.02 & 4.08 & 0.0662 \\
\hline E-Input Culture & 13.36 & 1 & 13.36 & 2709.62 & $<0.0001$ \\
\hline $\mathrm{AD}$ & 0.02 & 1 & 0.02 & 3.54 & 0.0843 \\
\hline $\mathrm{AE}$ & 0.21 & 1 & 0.21 & 43.53 & $<0.0001$ \\
\hline $\mathrm{BC}$ & 0.10 & 1 & 0.10 & 20.75 & 0.0007 \\
\hline $\mathrm{BE}$ & 0.08 & 1 & 0.08 & 15.24 & 0.0021 \\
\hline CE & 0.09 & 1 & 0.09 & 17.38 & 0.0013 \\
\hline $\mathrm{DE}$ & 0.07 & 1 & 0.07 & 13.98 & 0.0028 \\
\hline Residual & 0.06 & 12 & 0.00 & & \\
\hline Lack of Fit & 0.05 & 8 & 0.01 & 1.91 & 0.2788 \\
\hline Pure Error & 0.01 & 4 & 0.00 & & \\
\hline Cor Total & 14.87 & 23 & & & \\
\hline
\end{tabular}

Summary of ANOVA analysis on \% adhered in the resuscitation model.

\begin{tabular}{|l|c|c|c|c|c|}
\hline \multicolumn{1}{|c|}{ Source } & $\begin{array}{c}\text { Sum of } \\
\text { Squares }\end{array}$ & df & Mean Square & F Value & p-value Prob $>$ F \\
\hline Model & 7029.98 & 8 & 878.75 & 74.26 & $<0.0001$ \\
\hline
\end{tabular}




\begin{tabular}{|l|c|c|c|c|c|}
\hline A-Thaw Temp & 5.05 & 1 & 5.05 & 0.43 & 0.5236 \\
\hline B-Exposure Time & 116.87 & 1 & 116.87 & 9.88 & 0.0067 \\
\hline C-Dilution Media temp & 23.29 & 1 & 23.29 & 1.97 & 0.1810 \\
\hline D-Seeding Density & 87.85 & 1 & 87.85 & 7.42 & 0.0157 \\
\hline E-Input Culture & 6597.41 & 1 & 6597.41 & 557.50 & $<0.0001$ \\
\hline AE & 39.64 & 1 & 39.64 & 3.35 & 0.0871 \\
\hline BE & 97.67 & 1 & 97.67 & 8.25 & 0.0116 \\
\hline CE & 62.20 & 1 & 62.20 & 5.26 & 0.0367 \\
\hline Residual & 177.51 & 15 & 11.83 & & 0.5144 \\
\hline Lack of Fit & 132.95 & 11 & 12.09 & 1.08 & \\
\hline Pure Error & 44.56 & 4 & 11.14 & & \\
\hline Cor Total & 7207.49 & 23 & & & \\
\hline
\end{tabular}

Summary of ANOVA analysis on \% viability of adhered in the resuscitation model. 